\title{
The Structure of Persian Simple Sentences
}

\author{
Dr. Mehdi Rezaei \\ Assistant Professor in Salman Farsi University of Kazerun; Email: rezaeimehdi56@gmail.com \\ Dr. Raha Zareifard
}

Assistant Professor in Jahrom University; Email: rahazareifard@yahoo.com

\section{Doi:10.5901/jesr.2016.v6n1p94}

\section{Abstract}

Language teaching is an important device to expand and introduce culture to the other nations. Rule-governed structures are necessary for better understanding and learning of one language. This article aims at introducing the patterns of the structures of Persian simple sentences; moreover it describes these patterns with some examples from Persian to help the learners (especially non-native learners) have better understanding of them.

Keywords: Persian language, grammar, structure, sentence, verb, grammatical role.

\section{Introduction}

In Persian language, the sentences are the surface structures of discourse which have words as verbs and the set of words with a verb which have complete meaning will form simple sentences. The complex sentences include the combination of two simple sentences. Therefore, there are two structures for the Persian sentences: simple and complex sentences. In other words, the basic part of the structure of complex sentences is simple sentences and it is vital to understand the structure of simple sentences. Despite the value of this issue, most of the Persian grammar books have neglected the clear and deep descriptions of the structure of simple sentences. This article aims at investigating the common patterns of the structure of Persian simple sentences for the ease of language teaching and learning especially for non-native learners.

\section{Methodology}

In this article, we are going to suggest some patterns of Persian simple sentences. Since, our aim is the case of teaching grammar (especially for non - native learners), after reviewing literature, we discuss vital concepts in the description of simple sentences such as different kinds of verbs (linking, possessive, active, passive, transitive and intransitive verbs) with tangible examples. Our data (examples) gathered from daily discourse of Persian native speakers in Iran. Since most of the previous researches do not describe the structure of Persian Simple sentences clearly with tangible examples, in this article we are going to have descriptive-critical view toward the structure of Persian Simple sentences. At last, we propose patterns of Persian simple sentences with some simple instances with the aim of complete understanding of them.

\section{Literature Review}

Most of the Persian grammar books have ignored the complete and clear-cut analysis of the structure of Persian simple sentences. It is necessary to have a brief look at them.

Anvari and Givi (1995), have studied the structure of Persian simple sentences and have suggested eight patterns for them:

a. Subject+ subject complement+ linking verb

b. Subject+ intransitive verb

c. Subject+ object + transitive verb

d. Subject+ object +preposition+ complement+ intransitive verb or causatives 
e. Subject+ passive verb

f. Subject+ preposition+ complement+ passive verb

g. Subject+ object +object marker (OM)+ object complement+ non-perfect verb

h. Subject+ object complement+ passive non-perfect verb. (Anvari \& Givi,1995: 301-303)

Vahidiyan kamyar (2007), has also divided the structure of Persian simple sentences into eight categories:

a- Two-part sentences

1- Subject+ intransitive verb

b- Three-part sentences

2- Three parts with subject complement

3- Three parts with object

4- Three parts with complement

c- four-part sentences

5- four parts with object and complement

6- four parts with object and subject complement

7- four parts with two objects

8- four parts with complement and subject complement (Vahidiyan kamyar, 2007: 14-20)

There are some mistakes in the above categorizations. For instance, in number 7, the writer has mixed diachronic and synchronic view toward grammar; since "rā" acted as a preposition in past, it is mistaken with "rā" as object marker $(\mathrm{OM})$ in synchronic view. This can be observed in the following instance:

$\begin{array}{lllll}\text { mādar } & \text { kudak } & \text { rā } & \text { ghazā } & \text { dād } \\ \text { mother } & \text { child } & \text { to } & \text { food } & \text { gave }\end{array}$

"the mother gave food to the child"

Nowadays, nobody use "rā" in these kinds of structures as OM, but as a preposition.

Meshkatodini (2009: 225-242), in the sentence discussion, has emphasized on the structures of phrases, tense and mood but the structure of simple sentences have been ignored. In this regard, Rahimiyan (2002:114) has stated: "the commonest word order in Persian language is subject, object and verb (SOV). Moreover, Meshkotodini (1995: 48-56), has discussed about only one structure, i.e. "subject+ predicate" and then has focused on the phrases which can be substituted in these two locations.

Khayampur (2005: 23-27) has also categorized Persian sentences in two categories: nominal sentences and verbal sentences. He believed that verbal sentences include nominal sentences.

Darzi (2005: 183), with linguistic point of view, has suggested two patterns for the structure of simple sentences: a) $N P+N P+V P, b) N P+V P$; for instance in the following example:

Hasan ali rā mišenāsad

Hasan Ali OM has known

"Hasan has known Ali"

Hasan is an NP and Ali is also an NP and mišenāsad is a VP. In the second structure, VP (ali rā mišenāsad) itself consisted NP (Ali) and VP (mišenāsad).

Finally, Miremadi (1997: 108), has not clearly described the structure of simple sentences but only speaks about NP and VP and the structure of them.

As it can be observed in the review, none of the researchers have discussed clearly about the structure of simple sentences which is useful for language learners. The authors of this article try to fill this gap in the previous studies in Persian language.

\section{Theoretical Framework}

For the investigation of the structure of Persian simple sentences, we should describe different kinds of Persian verbs. The mood and meaning of verbs are important in receiving different roles, for instance, transitive verbs need object or some verbs need different kinds of adverbs to transfer definite concept. So in this part different aspects of Persian verbs are introduced.

\subsection{Different verbs according to function and content}

We can divide verbs into four groups according to their function and content. 


\subsubsection{Linking verbs}

The verb "ast" (is) and "būd" (was) and "bāšad" (be) with other morphological forms, are used for relating two words together, so we called them linking verbs. According to khayyāmpur's diachronic research, only the verb "ast" is linking verb (khayyāmpur, 2005: 23-7).

$\begin{array}{llllll}\text { example } & 1 . & \begin{array}{l}\text { havā } \\ \text { weather hot }\end{array} & \begin{array}{l}\text { garm } \\ \text { is }\end{array} & \text { ast } & \text { (present) } \\ \text { example } & 2 . & \begin{array}{l}\text { havā } \\ \text { weather hot } \\ \text { havā } \\ \text { wheather hot }\end{array} & \begin{array}{l}\text { garm } \\ \text { was }\end{array} & \begin{array}{l}\text { garm } \\ \text { be }\end{array} & \text { mibāšad }\end{array}$

("mibāšad" is present but in contrary to "ast" we can make imperative form like example 4. )

example 4. garm bāš (imperative)

In the abovementioned examples, the function of verbs are relating the hotness to the weather; in other words, attributing hotness to the weather. So, we call these three verbs, linking verbs. Therefore, in the abovementioned examples, "havā" (weather) is the subject and "garm" is subject complement and "ast" and "būd" are linking verbs.

\subsubsection{Possessive verbs}

The verb "dāšt" (had) with all of its morphological forms (like "dārad"( has, have) are employed for showing the possession. Its first function is showing possession and the next function is representing continuous action (khānlari, 1998: $\left.2^{\text {nd }} v: 144\right)$.

$\begin{array}{llllll}\text { example } & \text { 1. } & \begin{array}{l}\bar{u} \\ \text { he }\end{array} & \begin{array}{l}\text { khodkhār } \\ \text { pen }\end{array} & \text { dārad } & \text { has } \\ \text { example } & \text { 2. } & \begin{array}{l}\text { zeinab } \\ \text { huš-e- }\end{array} & \text { ziādi } & \text { dārad } \\ \text { inainab } & \text { intelligence } & \text { very } & \text { has } \\ \text { example } & \text { 3. } & \begin{array}{l}\text { ahmad } \\ \text { ahmad }\end{array} & \text { māšine } & \text { gerāni } & \text { dāšt } \\ & & \text { expensive } & \text { had }\end{array}$

\subsubsection{Changing verbs}

"šodan", "gaštan" and "gardidan" with all the morphological structures (present, past, present perfect, past perfect, ...) used for showing change, are called changing verbs.

These kinds of verbs are called "seirurat" in Arabic.

\begin{tabular}{|c|c|c|c|c|c|c|}
\hline example & 1. & $\begin{array}{l}\text { havā } \\
\text { weather } \\
\text { havā } \\
\text { weather } \\
\text { sard }\end{array}$ & $\begin{array}{l}\text { cold } \\
\text { cold } \\
\text { šow }\end{array}$ & $\begin{array}{l}\text { sard } \\
\text { became } \\
\text { sard } \\
\text { become } \\
\text { (imperative) }\end{array}$ & $\begin{array}{l}\text { šod } \\
\text { mišavad }\end{array}$ & $\begin{array}{l}\text { (past) } \\
\text { (present) }\end{array}$ \\
\hline example & 2. & $\begin{array}{l}\text { havā } \\
\text { weather } \\
\text { havā } \\
\text { weather } \\
\text { sard }\end{array}$ & $\begin{array}{l}\text { cold } \\
\text { cold } \\
\text { gard } \\
\text { cold }\end{array}$ & $\begin{array}{l}\text { sard } \\
\text { became } \\
\text { sard } \\
\text { become } \\
\text { (imperative) } \\
\text { become }\end{array}$ & $\begin{array}{l}\text { gašt } \\
\text { migardad } \\
\text { ) }\end{array}$ & $\begin{array}{l}\text { (past) } \\
\text { (present) }\end{array}$ \\
\hline example & 3. & $\begin{array}{l}\text { havā } \\
\text { weather } \\
\text { havā } \\
\text { weather } \\
\text { sard }\end{array}$ & $\begin{array}{l}\text { cold } \\
\text { cold } \\
\text { gard } \\
\text { cold }\end{array}$ & $\begin{array}{l}\text { sard } \\
\text { become } \\
\text { sard } \\
\text { become } \\
\text { (imperative) } \\
\text { become }\end{array}$ & $\begin{array}{l}\text { gardid } \\
\text { migardad } \\
\text { ) }\end{array}$ & $\begin{array}{l}\text { (past) } \\
\text { (present) }\end{array}$ \\
\hline
\end{tabular}


In some grammar books, these verbs are also called linking verbs (Anvari, 1995: 68; Khatibrahbar, 2002: 231; Meškatoddini, 2009: 92; Afraši, 2009: 124). But these verbs do not represent linking at all, they represent the revolution from one situation to another situation. By considering the structure of the sentences with these verbs, we can find that the application of these verbs are also different.

$\begin{array}{lllll}\text { example } & 1 . & \begin{array}{l}\text { havā } \\ \text { weather }\end{array} & \text { garm } & \text { ast } \\ \text { hot } & \text { is } \\ \text { example } & 2 . & \text { whā } & \text { garm } & \text { šod } \\ & & \text { wheather } & \text { hot } & \text { became }\end{array}$

In example 1, the linking "ast" only attribute hotness to the weather in the present time, but in example 2. Which has "šod", it shows the change of the pervious situation (coldness) to the present situation (hotness).

Another point is this question: in example 2. should we consider "šod" as a verb or the group "garm šod"? It seems that "garm šod" is complex passive verb, which, in this case, (šod) is not linking verb:

$\begin{array}{lllll}\text { example boxāi havā } & \text { rā } & \text { garm kard } \\ & \text { heater weather } & \text { OM } & \text { hot } & \text { do }\end{array}$

In this example, there is no doubt that "garm kard" is the complex transitive active verb (i.e. it needs subject and object). If we turn it into passive we have "havā garm šod" that is in this sentence and other sentences with " šod", "gašt" and "gardid", these verbs are auxiliaries for the structure of passive complex verb and are not linking verbs. Therefore, if we o not consider them as auxiliaries, for making passive, we consider them as "changing verbs".

\subsubsection{Absolute verbs}

We call the verbs with a kind of action in their content, absolute verbs. All Persian verbs except "ast","dāšt", "būd',"bāšad", "šod", "gašt", and "gardid" (which we discussed earlier) are called absolute verbs. All the abovementioned verbs, needs other parts for making the sentence, for instance, linking verbs need subject and another adjective or noun as subjective complements. "šod" with adjective make passive complex verb which attribute a change into the subject. Possessive verbs represent possession of person or thing for other persons or things.

$\begin{array}{llll}\text { Example: } & \text { minā aghl dārad } \\ & \text { Mina wisdom has }\end{array}$

In this example "mina" is in the subject position but "aghl" is not object because there is no action, but this is possessive relation between them and we do not need object marker.

\subsection{Intransitive, transitive, causative}

Absolute verbs need other parts like object, object complement or obligatory complement to represent definite function and meaning. So the discussion of intransitive, transitive and causative are subsections of the discussion of absolute verbs and it is not related to linking, changing and possessive verbs. Since we are going to discuss the structure of Persian simple sentences we should consider the subparts of absolute verb.

If absolute verb needs a word in the subject position to represent complete sentence, it is called intransitive verb. If absolute verb needs another word as object, it is called transitive verb. If it needs preposition and obligatory complement, it is called causative verb. Some verbs need both object and obligatory complement. In this case, we call them causative transitive verbs.

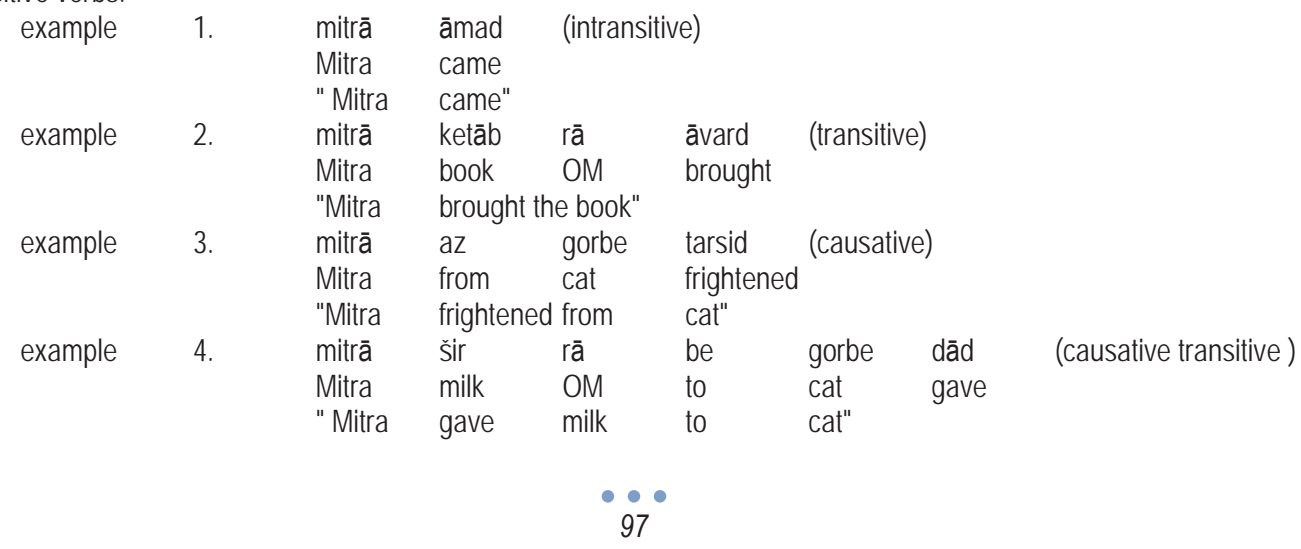


In the above mentioned examples, "Mitra " is the subject, "ketab" and "šir" are objects and "gorbe" is obligatory complement.

\subsection{Active and passive}

The discussion of active and passive verbs is also related to subject, object and obligatory complement. The subject of intransitive verbs cannot be deleted. If it is deleted, we have pronoun in the place of subject.

example. raft

went $+\varnothing$

In this example, apparently, the subject is deleted but third person pronoun hide in the verb.

Sometimes the subject and obligatory complement of transitive verb and causative can be deleted. In this case we encounter passive verbs.

\begin{tabular}{|c|c|c|c|c|c|c|c|c|}
\hline example & 1. & $\begin{array}{l}\text { mitrā } \\
\text { Mitra } \\
\text { ketāb }\end{array}$ & $\begin{array}{l}\text { ketāb } \\
\text { book } \\
\text { āvarde }\end{array}$ & $\begin{array}{l}\text { rā } \\
\text { OM }\end{array}$ & $\begin{array}{l}\text { āvard } \\
\text { brought } \\
\text { šod }\end{array}$ & $\begin{array}{l}\text { (active) } \\
\text { (passive) }\end{array}$ & & \\
\hline example & 2. & $\begin{array}{l}\text { book } \\
\text { mitrā } \\
\text { Mitra } \\
\text { mitrā }\end{array}$ & $\begin{array}{l}\text { brought } \\
\text { az } \\
\text { from } \\
\text { tarside }\end{array}$ & $\begin{array}{l}\text { become } \\
\text { gorbe } \\
\text { cat }\end{array}$ & $\begin{array}{l}\text { tarsid } \\
\text { frightened } \\
\text { šod }\end{array}$ & $\begin{array}{l}\text { (active) } \\
\text { (passive) }\end{array}$ & & \\
\hline example & 3. & $\begin{array}{l}\text { Mitra } \\
\text { mitrā } \\
\text { Mitra } \\
\text { šir } \\
\text { milk }\end{array}$ & $\begin{array}{l}\text { frightend } \\
\text { šir } \\
\text { milk } \\
\text { be } \\
\text { to }\end{array}$ & $\begin{array}{l}\text { become } \\
\text { rā } \\
\text { OM } \\
\text { gorbe } \\
\text { cat }\end{array}$ & $\begin{array}{l}\text { be } \\
\text { to } \\
\text { khorānde } \\
\text { eaten }\end{array}$ & $\begin{array}{l}\text { gorbe } \\
\text { cat } \\
\text { šod }\end{array}$ & $\begin{array}{l}\text { dād } \\
\text { gave } \\
\text { (passive) } \\
\text { become }\end{array}$ & (active) \\
\hline
\end{tabular}

In the first example "āvard" (active) turned to "āvarde šod" (passive) and the subject deleted and object replaced the subject position (in Persian, the place of subject should be filled).

In example 2, "Mitra" which is the subject of the active verb is not deleted; instead of "Mitra", obligatory complement is deleted. For more explanation, we should mention that in the causative structures, instead of subject, obligatory complement can be deleted in passive form.

These sentences are surface structures, if we consider deep - structure, we can see the transfer of main parts of the sentences.

$\begin{array}{llllll}\text { example } & 1 . & \text { mitrā } & \text { az } & \text { gorbe } & \text { tarsid (surface structure) } \\ & & \text { Mitra } & \text { from } & \text { cat } & \text { frightened } \\ \text { example } & 2 . & \text { gorbe } & \text { mitrā } & \text { rā } & \text { tarsānd (deep structure) } \\ & & \text { cat } & \text { Mitra } & \text { OM } & \text { frightened }\end{array}$

In example 2, (deep- structure), real subject is "gorbe" (cat) and "Mitra" is the object. Therefore, when we are going to make passive, we should turn to the deep structure; like other passive verbs, in these verbs (causative verbs) also the real subject in the deep -structure should be deleted.

In example 3, since we have subject, object and obligatory complement, like transitive verbs, the subject should be deleted in passive forms.

\subsection{The mood of the verbs}

Like meaning and content of verbs, mood is also important in the structure of Persian simple sentences. Mood is the manner of doing the action of the verb or the manner of attributing verb which is certain or conditional. In other words, mood is the speaker's or writer's idea toward happening of the verb, certainly it will occur or not (Vahidiān kāmyār, 2002:53).

In another definition "mood is one aspect of the verb which represent declaration, possibility imperativeness, wish, hope,..." (Faršidvard, 2003:77). subjunctive.

In this part, we discuss only two moods which are important in the structure of Persian sentences: declarative and 


\subsubsection{Declarative mood}

In declarative mood, the degree of certainty is important. In other words, it declares the action of the verb and does not need another part or certain condition. In adjectival mood is also, there is no doubt that the action occurred.
example:
hasan be
madrese rafte dar
konkūr
Hasan to school went in
entrance exam
movafagh šod

"Hasan has gone to school and succeeded in entrance exam."

The verb "rafte" is in adjectival mood but it declares certain tense, person.

Infinitival mood is also a kind of declarative mood.

$\begin{array}{llll}\text { example: natavān raft, } & \text { bāyād šenid } & \\ & \text { cannot } & \text { go, } & \text { must listen }\end{array}$

\subsection{2 subjunctive mood}

In subjunctive mood, for declaring the meaning of the verb clearly, we need another part such as adverb, another verb or another sentence. In this kind of mood, verb represents wish, uncertainty, condition, ... (Faršidvard, 2003: 295).

$\begin{array}{llll}\text { example } 1 . & \text { hasan be madrese beravad } \\ \text { Hasan to school if go }\end{array}$

"If Hasan go to school..."

In this example, the listener waits for another part to understand the meaning of the sentence completely. Some grammarians, called this kind of verbs conditional (because sometimes need conditional adjective) or other names, but it is not necessary. Since the necessity of another part is obvious in the subjunctive mood.

In this part, we discussed vital concept in the description of the structure of Persian simple sentences. In the next section, we will propose different structures of these sentences to have the clear- cut patterns of them.

\section{The Proposed Structures of Persian Simple Sentences}

Some of the essential roles which cannot be omitted in the sentences are called main parts and the other roles which could expand the sentences and cannot be omitted are called peripheral parts. According to the internal content of verbs, transitive, intransitive, causative, mood, active and passive verbs, some patterns can be introduced for the structure of Persian simple sentences. These 14 patterns are as the followings:

a) Two-part structure

1) Subject+ intransitive verb

ex: ū āmad
he came
"he came"
Subject+ passive verb
ex. došman dide šod
Enemy observed be
"The enemy has been observed"

b) Three-part structure

3) Subject+ Subject complement+ linking verb
ex. Ali zirak ast
Ali clever is

"Ali is clever"

4) Subject+ object+ transitive verb

$$
\begin{array}{clll}
\text { ex: hasan } & \text { gol } & \text { rā } & \text { čid } \\
\text { Hasan } & \text { flower } & \text { OM } & \text { picked }
\end{array}
$$

"Hasan picked up the flower"

5) Subject+ obligatory complement+ causative verb
ex: bače
az
gorbe
mitarsad
Child from cat has frightened

"The child has frightened from the cat" 
6) obligatory adv.+ subject+ intransitive subjunctive verb

ex: šāyad ù biyāyad
maybe he come

"he may come"

7) obligatory adv.+ subject+ transitive passive verb

ex: agar došman dide bešavad

if enemy seen has been

"if the enemy has been seen"

\section{c) four-part structure}

8) subject+ object+ obligatory complement+ causative transitive verb
ex: kešāvarz
āb
rā be
mazraPe resānd
farmer
water
OM to
farm transformed

"The farmer transformed the water to the farm"

9) subject+ object+ object complement+ particular verb
ex: hamkelāsihā vey
rā Edison
mikhāndand
classmates he
$\mathrm{OM}$
Edison called

"the classmates called him Edison"

10) obligatory adv.+ subject+ subject complement+ subjunctive linking verb

ex: šāyad ali dānā bāšad
maybe Ali wise be

" Ali may be wise"

11) obligatory adv.+ subject+ object + subjunctive transitive verb

"Hasan may picked up the flower"

12) Obligatory adv. + subject+ obligatory complement+ causative intransitive verb
Ex: šāyad moxālefān
darbāreye jang esrār karde bāšand Maybe oppositions
about war insist did
be

\section{d) Five- part structure}

"The oppositions may be insisted about the war"

13) Obligatory adverb + subject + object + obligatory complement + subjunctive causative intransitive verb

Ex: kāš vey tavānāiyaš rā be hame bešnāsānad

$$
\text { If he abilities on to all known }
$$

"I hope he gets the abilities to be known to everyone"

14) Obligatory adverb + subject + object+ object complement+ subjunctive particular verb

Ex: bāyad mā ù rā behtarin bedānim

Must we he OM best known

"We must know him as the best"

\section{Conclusion}

1. There are fourteen patterns for the structure of Persian simple sentences.

2. Subjunctive as well as declarative are important in the structure of these fourteen patterns.

3. Intransitive, transitive, causative, active, passive and particular verbs and mood are the most important factors of these patterns.

4. Seven main roles of Persian simple sentence are: verb, subject, subject complement, object, object complement, obligatory complement and obligatory adverb.

5. Two main roles of these seven roles could be found in all structure: verb and subject.

6. Obligatory adverb is one of the main roles in the structure of Persian simple sentences which is ignored up to now and it is necessary to use them with subjunctives.

7. If there is linking verb, in addition to the subject and verb, subject complement is also necessary.

8. If there is active transitive verb, in addition to the verb and subject, object is also needed.

9. If there is causative or causative - transitive verb, obligatory complement is needed. 
10. If there is particular verb, in addition to subject, object and verb, object complement is also necessary.

11. According to the linguistic needs, the structure of the simple sentences can be expanded with the peripheral roles (secondary roles).

\section{References}

Abolghasemi, M. (2006). Dari Persian Verb Roots. Tehran: Ghoghnus.

Afrashi, A. (2009). The Structure of Persian Language. Tehran: SAMT.

Anvari, H. \& Ahmadi givi, H. (1995). Persian Language Grammar. 2nd V. Tehran: Fatemi Press.

Natel khanlari, P. (1998). The History of Persian Language. Tehran: Ferdos.

Khatib rahbar, kh. (2002). Persian Language Grammar. Tehran: Mahtab Press.

Khayyampur, A. (2005). Persian Language Grammar. Tehran: Sotude Press.

Darzi, A. (2005). Syntactic Argumentation. Tehran: SAMT.

Rahimiyan, J. (2002). Persian Grammar, Form, Function and Meaning. Shiraz: Shiraz University Press.

Farshidvard, Kh. (2003). Extended Today's Grammar. Tehran: Sokhan Press.

Farshidvard, Kh. (2004). V\& VP \& it's Revolutions in Persian Language. Tehran: Sorush.

Farshidvard, Kh. (2009). Abridged Today's Grammar on the base of Modern Linguistcs. Tehran: Sokhan Press.

Meshkatoddini, M. (1995). Persian Transformational Syntax. Mashhad: Mashhad University Press.

Meshkatoddini, M. (2009). Persian Language Grammar, Lexicon \& Structural Links. Tehran: SAMT.

Miremadi, A. (1997). Persian Syntax (According to G-B). Tehran: SAMT.

Natel khanlari, P. (1998). Persian Language History. Tehran: Ferdows.

Vahidiyan Kamyar, T. \& Omrani, Gh. (2007). Persian Language Grammar 1. Tehran: SAMT. 